\section{BMJ Open \\ Respiratory \\ Research}

\title{
Serum levels of immunoglobulins and severity of community-acquired pneumonia
}

\author{
Mari C de la Torre, ${ }^{1}$ Pere Torán, ${ }^{2}$ Mateu Serra-Prat, ${ }^{3}$ Elisabet Palomera, ${ }^{3}$ \\ Estel Güell, ${ }^{4}$ Ester Vendrell, ${ }^{4}$ Joan Carles Yébenes, ${ }^{4}$ Antoni Torres, ${ }^{5}$ Jordi Almirall ${ }^{4}$
}

To cite: de la Torre MC, Torán $\mathrm{P}$, Serra-Prat $\mathrm{M}$, et al. Serum levels of immunoglobulins and severity of communityacquired pneumonia. BMJ Open Resp Res 2016;3: e000152. doi:10.1136/ bmjresp-2016-000152

- Additional material is available. To view please visit the journal (http://dx.doi.org/ 10.1136/bmjresp-2016000152)

Received 19 July 2016 Revised 10 October 2016 Accepted 11 October 2016

\section{ABSTRACT}

Instruction: There is evidence of a relationship between severity of infection and inflammatory response of the immune system. The objective is to assess serum levels of immunoglobulins and to establish its relationship with severity of communityacquired pneumonia (CAP) and clinical outcome.

Methods: This was an observational and crosssectional study in which 3 groups of patients diagnosed with CAP were compared: patients treated in the outpatient setting $(n=54)$, patients requiring inpatient care (hospital ward) $(n=173)$, and patients requiring admission to the intensive care unit (ICU) $(n=191)$.

Results: Serum total $\lg G$ (and IgG subclasses $\lg G 1$, $\lg G 2, \lg G 3, \lg G 4), \lg A$ and $\lg M$ were measured at the first clinical visit. Normal cutpoints were defined as the lowest value obtained in controls $(\leq 680, \leq 323, \leq 154$, $\leq 10, \leq 5, \leq 30$ and $\leq 50 \mathrm{mg} / \mathrm{dL}$ for total $\operatorname{lgG}, \lg \mathrm{G} 1$, $\lg G 2, \lg G 3$, IgG4, IgM and IgA, respectively). Serum immunoglobulin levels decreased in relation to severity of CAP. Low serum levels of total IgG, IgG1 and IgG2 showed a relationship with ICU admission. Low serum level of total IgG was independently associated with ICU admission (OR=2.45, 95\% $\mathrm{Cl} 1.4$ to 4.2, $\mathrm{p}=0.002)$, adjusted by the CURB-65 severity score and comorbidities (chronic respiratory and heart diseases). Low levels of total $\lg G, \lg G 1$ and $\lg G 2$ were significantly associated with 30-day mortality. Conclusions: Patients with severe CAP admitted to the ICU showed lower levels of immunoglobulins than non-ICU patients and this increased mortality.

\section{INTRODUCTION}

CrossMark

For numbered affiliations see end of article.

Correspondence to Dr Mari $\mathrm{C}$ de la Torre; mctorre@csdm.cat
Community-acquired pneumonia (CAP) remains one of the infectious diseases with the highest morbidity and mortality. In the general adult population, the annual incidence of CAP varies between 1.6 and 13.4 cases per 1000 inhabitants, and hospitalisation rates range between $22 \%$ and $61.4 \% .^{1{ }^{2}}$ Approximately $10 \%$ of hospitalised patients require admission to the intensive care unit

\section{KEY MESSAGES}

Low levels of immunoglobulins are a prognostic factor of severity in community pneumonia?

Patients with severe community-acquired pneumonia (CAP) admitted to the intensive care unit (ICU) showed lower levels of circulating immunoglobulins than non-ICU patients and this observation is associated with an increased mortality.

- These findings suggest that we should continue the investigation of the target subgroup of patients with CAP where the use of intravenous immunoglobulin as adjunctive treatment may improve outcome and reduce mortality.

(ICU). ${ }^{3}$ The mortality rate varies between 0.1 and 0.7 per 1000 persons-year. $^{1-5}$

There is evidence of the relationship between severity of infection and inflammatory response of the immune system. ${ }^{6} \quad 7$ Immunoglobulins (IgG subclasses) are particularly effective in the identification, neutralisation, opsonisation and direct lysis of pathogens as well as activation of the complement cascade. Owing to these specific functions, immunoglobulins are postulated as new therapies, already used in the treatment of primary humoral immunodeficiency, ${ }^{8-11}$ autoimmune diseases ${ }^{11}$ and neonatal streptococcal septic shock. ${ }^{12}$ Treatment with intravenous immunoglobulin (IVIG) is a promising adjunctive therapy for severe sepsis and septic shock, but its use remains controversial, although an overall mortality benefit has been reported in small studies. ${ }^{13}$

It is well known that a deficit in immunoglobulin production, especially IgG in primary immunodeficiencies, causes an increase in infections, in particular by encapsulated pathogens of the upper (sinusitis, tracheobronchitis) or lower (pneumonia) respiratory tract. However, there is little information on changes in serum levels of 
immunoglobulins in previously healthy subjects diagnosed with pneumonia. Therefore, a cross-sectional study in patients with CAP was conducted, the aim of which was to assess serum levels of immunoglobulins and to establish a relationship with severity of pneumonia and clinical outcome.

\section{METHODS}

\section{Design and setting}

This was an observational and cross-sectional study in which three groups of patients diagnosed with CAP were compared. The diagnosis of CAP was based on acute lower respiratory tract infection with the appearance of focal signs on physical examination of the chest and new radiological findings suggestive of pulmonary infiltrate. ${ }^{12}$ The three study populations were patients with CAP treated at home, patients with CAP requiring inpatient care, and patients with CAP requiring admission to the ICU. ${ }^{14}$ All patients gave written consent to draw blood samples for the immunological study on the first day of the patient-physician encounter. Written informed consent was obtained directly from all patients or their legal representative before enrolment. The study protocol was approved by the Ethics Committee of the Consorci Sanitari del Maresme (Barcelona, Spain).

Exclusion criteria and other study details, including data collected for each patient, are described in the online supplementary data.

Prognostic data included were septic shock, defined by persistent hypotension despite fluid replacement therapy associated with signs of hypoperfusion, and 30-day mortality. Severity of CAP at the first evaluation of the patient was estimated using the CURB-65 severity score. $^{15}$

\section{Immunological study}

Blood samples were obtained from all patients during the first contact with the physician and at the time of diagnosis of $\mathrm{CAP}$, and were stored at $-80^{\circ} \mathrm{C}$ until analysis. Serum total IgG (and IgG subclasses IgG1, IgG2, IgG3, IgG4), IgA and IgM were measured by nephelometry. ${ }^{16}$ Since standard criteria regarding normal values of immunoglobulins are lacking, reference values were those obtained in a control group of the same population (see online supplementary data) ${ }^{17}$ In patients with CAP, normal cutpoints for serum concentration of immunoglobulins or IgG subclasses was defined as the lowest value obtained in controls, which were $680 \mathrm{mg} / \mathrm{dL}$ for IgG, $323 \mathrm{mg} / \mathrm{dL}$ for IgG1, $154 \mathrm{mg} / \mathrm{dL}$ for IgG2, $10 \mathrm{mg} / \mathrm{dL}$ for IgG3, $5 \mathrm{mg} / \mathrm{dL}$ for IgG4, $30 \mathrm{mg} / \mathrm{dL}$ for IgM, and $50 \mathrm{mg} / \mathrm{dL}$ for IgA. Hypogammaglobulinaemia was defined as a serum IgG level $<500 \mathrm{mg} / \mathrm{dL}^{18}$

\section{Statistical analysis}

Immunoglobulin levels in each of the three study groups (ambulatory CAP, hospitalised patients with CAP, patients with CAP admitted to the ICU) were expressed as median and IQR (25-75th centile) and also categorised as low (deficient) or normal levels according to the cutpoints for serum levels of immunoglobulins and IgG subclasses. Ambulatory patients with CAP or those requiring inpatient care were grouped in a single category of non-ICU patients with CAP in order to compare this category with patients with CAP admitted to the ICU. All factors associated with low serum levels of immunoglobulins were analysed. Means were compared with the analysis of variance (ANOVA) or the Kruskal-Wallis test (three groups) or Student's t-test or the Mann-Whitney $U$ test (two groups). The Spearman correlation coefficient $\left(r_{s}\right)$ was used to assess the relationship between continuous variables. The effect of serum levels of immunoglobulins on ICU admission was assessed in a logistic regression analysis, and the OR and 95\% CIs were calculated. The model was adjusted by confounding variables associated with both serum levels of immunoglobulins and ICU admission. Statistical significance was set at $\mathrm{p}<0.05$. The SPSS program (V.11.0) was used for data analysis.

\section{RESULTS}

\section{Study population and baseline characteristics}

A total of 876 patients diagnosed with CAP were enrolled and classified into groups of ambulatory CAP $(\mathrm{n}=246)$, CAP requiring hospitalisation $(\mathrm{n}=244)$, and CAP requiring care in the ICU $(n=386)$. However, 458 $(52.3 \%)$ patients were excluded in most cases $(n=374)$ because blood samples on the day of CAP diagnosis were unavailable. The flow chart of the study population is shown in figure 1 . The three study groups included 54 patients with CAP treated in the outpatient setting, 173 admitted to the hospital, and 191 admitted to the ICU. Baseline characteristics of the patients are shown in table 1 .

\section{Serum immunoglobulin levels}

As shown in table 2, serum immunoglobulin levels decreased in relation to severity of CAP, that is, patients requiring ICU admission showed significantly lower values of all IgG subclasses and IgA as compared with patients with CAP treated in the outpatient setting or admitted to the hospital. Serum immunoglobulins except for total IgG were higher in ambulatory CAP as compared with hospitalised patients, who also showed higher levels as compared with patients admitted to the ICU.

The correlation between serum immunoglobulin levels and days with symptoms prior to medical diagnosis of CAP showed a significant and positive correlation between IgG2 levels and days with symptoms in patients not requiring ICU admission $\left(\mathrm{r}_{\mathrm{s}}=0.145, \mathrm{p}=0.035\right)$, whereas in patients admitted to the ICU there was a negative correlation between days of previous symptoms and serum levels of total IgG $\left(r_{s}=-0.216, p=0.003\right), \operatorname{IgG} 1$ $\left(r_{s}=0.201, p=0.005\right)$ and IgG2 $\left(r_{s}=-0.175, p=0.016\right)$. 
Figure 1 Flow chart of the study population. CAP,

community-acquired pneumonia; ICU, intensive care unit.

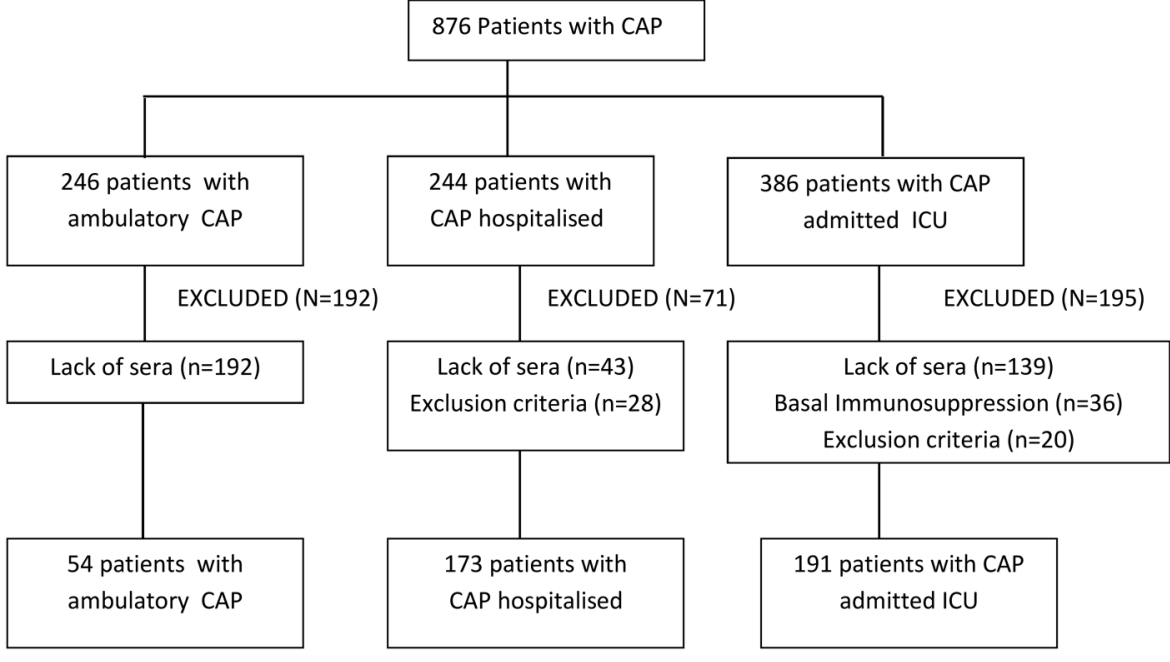

\section{Low serum immunoglobulin levels}

As shown in table 3, low serum levels of total IgG, IgG1 and IgG2 (according to the reference values) showed a relationship with ICU admission. Differences in the percentage of patients with low immunoglobulin levels between those treated in the outpatient setting and those admitted to the hospital ward were not observed. However, there was a statistically significant association between low levels of total IgG and IgG1 and higher values in the CURB-65 severity score (table 4). All patients with a CURB-65 severity score of 4 and 5 were admitted to the ICU.

In the multivariate analysis, a low serum level of total IgG was independently associated with ICU admission $(\mathrm{OR}=2.45,95 \%$ CI 1.4 to $4.2, \mathrm{p}=0.002)$, adjusted by the
CURB-65 severity score and comorbidities (chronic respiratory and heart diseases) (table 5).

\section{0-day mortality}

Of the 418 patients with CAP, 48 (11.5\%) died within 30 days after diagnosis. In relation to the CURB-65 severity score, the mortality rate was $100 \%$ for patients with score $5,28.6 \%$ for score $4,20.6 \%$ for score $3,18.7 \%$ for score 2 and only $2.2 \%$ for score 1 . Admissions to the hospital and to the ICU were both associated with mortality. Also, low levels of total IgG, IgG1 and IgG2 were significantly related to fatality (figure 2). Patients with hypogammaglobulinaemia (total $\mathrm{IgG}<500 \mathrm{mg} / \mathrm{dL}$ ) $(n=23)$ also showed a higher mortality rate than the

Table 1 Baseline characteristics of the study population according to site of care

\begin{tabular}{|c|c|c|c|c|c|c|}
\hline \multirow[b]{2}{*}{ Variables } & \multicolumn{4}{|c|}{ Site of care of patients with CAP } & \multirow[b]{2}{*}{$\begin{array}{l}\text { p Value three } \\
\text { study groups }\end{array}$} & \multirow[b]{2}{*}{$\begin{array}{l}\text { p Value ICU vs } \\
\text { non-ICU groups }\end{array}$} \\
\hline & Ambulatory & $\begin{array}{l}\text { Hospital } \\
\text { ward }\end{array}$ & ICU & Non-ICU & & \\
\hline Total patients & 54 & 173 & 191 & 227 & & \\
\hline Male patients & $42(77.8)$ & $112(64.7)$ & $136(71.2)$ & $154(67.8)$ & 0.146 & 0.457 \\
\hline Age, years, mean (SD) & $51.1(18.8)$ & $71.1(15.6)$ & $60.1(17.4)$ & $66.3(18.5)$ & $<0.001$ & $<0.001$ \\
\hline Alcohol consumption & 7 (14) & $8(4.8)$ & $30(15.7)$ & $15(6.9)$ & 0.003 & 0.004 \\
\hline Smoking habit & $14(28)$ & $27(16.1)$ & $67(35.1)$ & $41(18.8)$ & $<0.001$ & $<0.001$ \\
\hline $\begin{array}{l}\text { Chronic respiratory } \\
\text { disease }\end{array}$ & $12(24)$ & $100(59.2)$ & $73(38.2)$ & $112(51.1)$ & $<0.001$ & 0.009 \\
\hline Chronic heart disease & $6(12)$ & $76(45)$ & $42(22)$ & $82(37.4)$ & $<0.001$ & 0.001 \\
\hline Diabetes mellitus & $2(4)$ & $41(24.3)$ & $44(23)$ & $43(19.6)$ & 0.006 & 0.401 \\
\hline $\begin{array}{l}\text { Chronic neurological } \\
\text { disorders }\end{array}$ & $5(10)$ & $29(17.2)$ & $19(9.9)$ & $34(15.5)$ & 0.101 & 0.093 \\
\hline Chronic renal failure & $1(2)$ & $8(4.7)$ & $7(3.7)$ & $9(4.1)$ & 0.663 & 0.817 \\
\hline Past solid neoplasm & $1(2)$ & $10(5.9)$ & $4(2.1)$ & $11(5.0)$ & 0.125 & 0.115 \\
\hline Oral corticosteroids & $5(10)$ & $30(17.8)$ & $8(4.2)$ & $35(16.0)$ & $<0.001$ & $<0.001$ \\
\hline $\begin{array}{l}\text { Previous symptoms, } \\
\text { days, mean (SD) }\end{array}$ & $7.6(5.6)$ & $4.5(5.3)$ & $3.5(2.9)$ & $5(5.5)$ & $<0.001$ & 0.069 \\
\hline Shock & 0 & 0 & $88(46.1)$ & 0 & $<0.001$ & $<0.001$ \\
\hline Death & 0 & $5(2.9)$ & $43(22.5)$ & $5(2.2)$ & $<0.001$ & $<0.001$ \\
\hline
\end{tabular}

Data as frequencies and percentages in parentheses unless otherwise stated.

$\mathrm{CAP}$, community-acquired pneumonia; ICU, intensive care unit. 
Table 2 Differences of serum levels of immunoglobulins in patients with CAP according to the site of care on the first day of medical consultation

\begin{tabular}{|c|c|c|c|c|c|c|}
\hline \multirow{2}{*}{$\begin{array}{l}\text { Serum levels of } \\
\text { immunoglobulins } \\
\text { (mg/dL) }\end{array}$} & \multicolumn{4}{|c|}{ Site of care of patients with CAP } & \multirow{2}{*}{$\begin{array}{l}\text { p Value } \\
\text { three } \\
\text { study } \\
\text { groups }\end{array}$} & \multirow{2}{*}{$\begin{array}{l}\text { p Value } \\
\text { ICU vs } \\
\text { non-ICL } \\
\text { groups }\end{array}$} \\
\hline & $\begin{array}{l}\text { Ambulatory } \\
(n=54)\end{array}$ & $\begin{array}{l}\text { Hospital ward } \\
(n=173)\end{array}$ & ICU (n=191) & Non-ICU $(n=227)$ & & \\
\hline IgG, total & $1110(889-1350)$ & $986.5(768.5-1175)$ & $908(682-1300)$ & $1010(810-1210)$ & 0.035 & 0.081 \\
\hline $\lg \mathrm{G} 1$ & $-815)$ & 608.5 & $541(401$ & 623 & 0.009 & 0.005 \\
\hline $\lg G 2$ & $339(239-506)$ & $318(209-430.5)$ & $270.5(162-369)$ & $323.5(221-447)$ & $<0.001$ & $<0.001$ \\
\hline $\lg G 3$ & $60.8(43.1-80)$ & $61.3(43.5-85.4)$ & $43.1(29-70)$ & $61.3(43.4-83.3)$ & $<0.001$ & $<0.001$ \\
\hline $\lg G 4$ & $46.8(27.7-103)$ & $43.3(18.6-74.5)$ & $28.5(15-58)$ & $44.7(21.4-80.9)$ & 0.001 & 0.001 \\
\hline $\lg A$ & $233(160-342)$ & $254(186-333)$ & $221.5(132-310)$ & $249(184-340)$ & 0.018 & 0.008 \\
\hline IgM & $107(58-162)$ & $76.5(53-121)$ & $83(58-117)$ & $81(54-129)$ & 0.032 & 0.705 \\
\hline
\end{tabular}

Data as median and IQR (25-75th centile) in parentheses.

CAP, community-acquired pneumonia; ICU, intensive care unit.

remaining patient, but it was not statistically significant $(\mathrm{p}=0.079)$.

\section{DISCUSSION}

To the best of our knowledge, this is the first study in which serum levels of immunoglobulins were measured in patients with CAP divided according to severity of pneumonia. We have observed that if the CAP is more severe, there is a lower concentration of IgG1, IgG2, IgG3 and IgG4 subclasses as well as IgA. In fact, patients requiring ICU admission as compared with those not treated in the ICU showed lower levels of circulating IgG1, IgG2, IgG3, IgG4 and IgA. Since no differences in serum concentrations of immunoglobulins between patients treated ambulatorily and patients treated in the hospital ward were observed, it seems that low immunoglobulin levels may occur exclusively in patients with severe CAP, and that low values of total IgG in the acute phase of CAP is an independent prognostic factor for ICU admission.

Although factors influencing the outcome of pneumonia have been extensively investigated, the potential effect of low immunoglobulin levels on mortality in CAP remains unclear. Moreover, it has been observed that low levels of total IgG, IgG1 and IgG2 at the onset of
CAP are indicator of a higher severity and an increased in mortality.

A few studies have assessed changes of serum immunoglobulin levels in pneumonia. Feldman et $a l^{19}$ measured IgG levels in 66 patients (19 patients required ICU treatment), and found abnormal levels (increase or decrease) in the IgG subclasses but without differences between ICU and non-ICU patients. These findings may be probably be explained by the small number of patients in both groups, particularly critically ill patients. In the present study, serum immunoglobulin levels were measured in a large study sample of 418 patients with CAP, which allowed stratification into two large subsets of 227 patients not requiring ICU admission and 191 severely ill patients treated in the ICU. We found significant differences in the four IgG subclasses, with lower values among patients admitted to the ICU. In contrast to findings in the study of Feldman $e t a l,{ }^{19}$ we found that low levels of total IgG, IgG1 and IgG2 may be prognostic factors of mortality and are more frequently observed in patients admitted to the ICU. In 1990, Herer et $a l^{20}$ reported that serum levels of IgG2 in patients with CAP $(n=38)$ of bacterial or unknown aetiology were lower than in healthy subjects $(\mathrm{n}=26)$, remaining low 9 months later. A comparison with healthy subjects was not made

Table 3 Patients with CAP and low levels of serum immunoglobulins according to the site of care

\begin{tabular}{|c|c|c|c|c|c|c|c|}
\hline \multirow[b]{2}{*}{$\begin{array}{l}\text { Low levels of serum } \\
\text { immunoglobulins, } \\
\text { mg/dL (cutpoints) }\end{array}$} & \multicolumn{4}{|c|}{ Site of care of patients with CAP } & \multirow{2}{*}{$\begin{array}{l}\text { p Value } \\
\text { three } \\
\text { study } \\
\text { groups }\end{array}$} & \multirow[b]{2}{*}{$\begin{array}{l}\text { p Value ICU } \\
\text { vs non-ICU } \\
\text { groups }\end{array}$} & \multirow[b]{2}{*}{ OR $(95 \% \mathrm{Cl})$} \\
\hline & $\begin{array}{l}\text { Ambulatory } \\
(n=54)\end{array}$ & $\begin{array}{l}\text { Hospital } \\
\text { ward } \\
(n=173)\end{array}$ & $\begin{array}{l}\text { ICU } \\
(n=191)\end{array}$ & $\begin{array}{l}\text { Non-ICU } \\
(n=227)\end{array}$ & & & \\
\hline IgG, total $(\leq 680)$ & $7(13)$ & $33(19.1)$ & 75 (39.3) & $40(17.6)$ & $<0.001$ & $<0.001$ & $3.03(1.94$ to 4.75$)$ \\
\hline $\operatorname{lgG1}(\leq 323)$ & $3(5.6)$ & $13(7.5)$ & $41(21.5)$ & $16(7.1)$ & $<0.001$ & $<0.001$ & 3.59 (1.94 to 6.63$)$ \\
\hline $\operatorname{lgG} 2(\leq 154)$ & $8(14.8)$ & $31(17.9)$ & $52(27.2)$ & $39(17.2)$ & $<0.04$ & $<0.013$ & $1.8(1.13$ to 2.89$)$ \\
\hline $\lg 33(\leq 10)$ & $1(1.9)$ & 0 & $5(2.6)$ & $1(0.4)$ & 0.108 & 0.098 & 6.05 (0.7 to 52.2$)$ \\
\hline $\operatorname{lgG} 4(\leq 5)$ & $3(5.6)$ & $7(4.0)$ & $5(2.6)$ & $10(4.4)$ & 0.544 & 0.328 & $0.58(0.2$ to 1.74$)$ \\
\hline $\lg A(\leq 50)$ & $1(2.0)$ & $4(2.3)$ & $7(3.7)$ & $5(2.2)$ & 0.683 & 0.389 & $1.60(0.81$ to 3.17$)$ \\
\hline $\lg M(\leq 30)$ & $3(5.6)$ & $13(7.5)$ & $21(11.0)$ & $16(7.1)$ & 0.366 & 0.173 & 1.66 (0.52 to 5.32$)$ \\
\hline
\end{tabular}

Data as frequencies and percentages in parentheses.

$\mathrm{CAP}$, community-acquired pneumonia; ICU, intensive care unit. 
Table 4 Association between low serum levels of immunoglobulins and CURB-65 score

\begin{tabular}{|c|c|c|c|c|c|c|c|}
\hline \multirow[b]{2}{*}{ Immunoglobulins cutpoints, mg/dL } & \multicolumn{6}{|c|}{ CURB-65 severity score } & \multirow[b]{2}{*}{ p Value } \\
\hline & $0(n=71)$ & $1(n=137)$ & $2(n=124)$ & $3(n=68)$ & $4(n=14)$ & $5(n=4)$ & \\
\hline $\operatorname{lgG}$, total $(\leq 680)$ & $14(19.7)$ & $29(21.2)$ & $36(29.0)$ & $28(41.2)$ & $5(35.7)$ & $3(75)$ & 0.005 \\
\hline $\operatorname{lgG} 1(\leq 323)$ & $6(8.5)$ & $11(8)$ & $17(13.7)$ & $18(26.5)$ & $3(21.4)$ & $2(50)$ & 0.001 \\
\hline $\lg G 2(\leq 154)$ & $11(15.5)$ & $30(21.9)$ & $22(17.7)$ & $23(33.8)$ & $4(28.6)$ & $1(25)$ & 0.113 \\
\hline $\operatorname{lgG} 3(\leq 10)$ & $1(1.4)$ & $2(1.5)$ & $2(1.6)$ & $1(1.5)$ & 0 & 0 & 0.998 \\
\hline $\operatorname{lgG} 4(\leq 5)$ & $5(7)$ & $2(1.5)$ & $6(4.8)$ & $2(3)$ & 0 & 0 & 0.353 \\
\hline $\lg A(\leq 50)$ & $2(2.8)$ & $4(2.9)$ & $2(1.6)$ & $3(4.4)$ & $1(7.1)$ & 0 & 0.820 \\
\hline $\operatorname{IgM}(\leq 30)$ & $4(5.6)$ & $9(6.6)$ & $12(9.7)$ & $10(14.7)$ & $2(14.3)$ & 0 & 0.331 \\
\hline
\end{tabular}

in our study. However, in a previous population-based case-control study, with 171 cases and 90 controls matched by age and sex, all immunoglobulins were significantly lower in cases than in controls, mainly total IgG and IgG2. ${ }^{17}$ In contrast to the study of Herer et $a l^{20}$ $80 \%$ of patients normalised immunological levels in the convalescent phase (after 30 days).

Similar results have been obtained in the studies of Gordon $e t a l^{21} 22$ in which a decrease in serum levels of total IgG, IgG1 and IgG2 in patients with CAP with severe influenza H1N1 virus pneumonia as well in the remaining patients with severe non-influenza CAP. Although Gordon et $a l^{11}{ }^{21}$ established an association between acute low values of IgG2 and severe infection by influenza $\mathrm{H} 1 \mathrm{~N} 1$ virus, they could not determine whether this was due to the virus itself or to other factors of severity. On the other hand, Justel et $a t^{33}$ observed that patients with severe disease caused by influenza A (H1N1) and low levels of IgG2 and IgM on ICU admission died sooner. In our study, we detected no differences in serum levels of IgM, perhaps because we excluded immunosuppressed patients. In this study, low levels of total IgG (below the reference cut-off value) was an independent risk factor for ICU admission in the logistic regression analysis, as was the CURB-65 severity score.

Clearly, there are levels of serum immunoglobulins lower in patients with severe CAP, but the reason for these decline is unknown. Hukuhara et $a l^{24}$ suggested that IgG2 are consumed at the infected phase by protecting against bacterial infections. In our study, ICU patients despite consult a physicians before patients no-ICU, showed lower IgG2 and also to further delay in

Table 5 Effect of low levels of serum IgG levels adjusted by independent risk factors on ICU admission

\begin{tabular}{llr}
\hline Variable & OR $(95 \%$ Cl $)$ & p Value \\
\hline Low level of total IgG & $2.45(1.4$ to 4.2$)$ & 0.002 \\
( $\leq 680 \mathrm{mg} / \mathrm{dL})$ & & \\
CURB-65 severity score & $4.62(3.33$ to 6.4$)$ & $<0.001$ \\
Chronic heart disease & $0.22(0.12$ to 0.4$)$ & $<0.001$ \\
Chronic respiratory disease & $0.29(0.17$ to 0.51$)$ & $<0.001$ \\
\hline ICU, intensive care unit. & &
\end{tabular}

diagnosis more decreased concentrations of this subclass. Regardless of the underlying mechanism responsible for the low levels of immunoglobulins, according to the present findings, patients with decreases in total IgG and IgG1, as well as IgG2, have a threefold and twofold increased risk of ICU admission, respectively, than patients with normal levels. Low levels of total IgG were found in $20.9 \%$ of patients who died as compared with $8 \%$ of survivors. In previous study in our group, showed as serum levels of IgG2 $(<301 \mathrm{mg} / \mathrm{dL})$ at the time of CAP diagnosis was a mortality predictor for hospitalised patients with CAP and patients with IgG2 levels below this cut-off died sooner. ${ }^{25}$ Of studies that have investigated the relationship between immunoglobulins and sepsis, Bermejo-Martín et $a l^{26}$ demonstrated that the combined presence of low levels of IgG1, IgM and IgA in plasma was associated with reduced survival for cases of severe sepsis or septic shock. These results suggest that we should continue the investigation of the target subgroup of patients with CAP, probably using immunoscores with different immunoglobulins to predict prognosis, whereas the use of IVIG as adjunctive treatment during the acute phase of the disease may improve outcome and reduce mortality.

Data supporting the use of IVIG remains controversial. Werdan $e t a l^{27}$ in a randomised, double-blind, placebocontrolled, multicentre trial (the SBITS study), the administration of intravenous monoclonal $\operatorname{IgG}$ did not

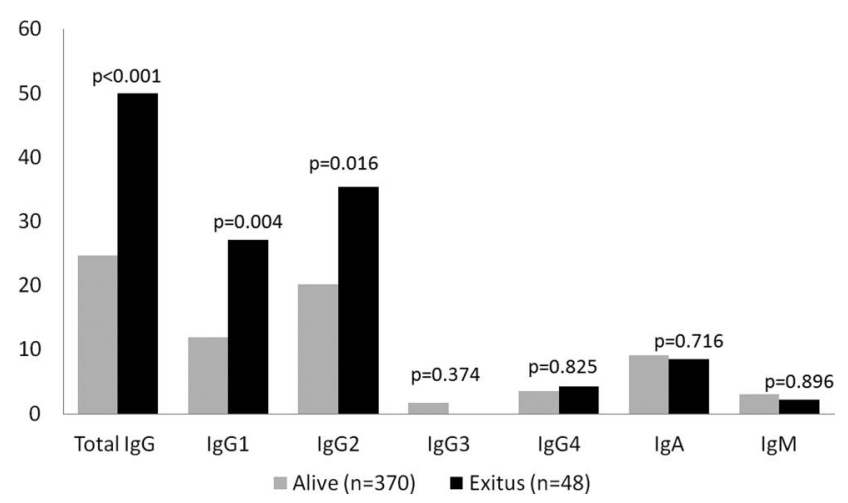

Figure 2 Low levels of serum immunoglobulins and effect on 30-day mortality. 
reduce 28-day mortality in patients with sepsis. However, studies with polyclonal IVIG have shown a reduction in mortality, with a trend in favour of immunoglobulin preparations enriched with IgM. ${ }^{28} 29$ Data of systematic reviews and meta-analyses provided evidence of the effect of polyclonal IVIG to reduce mortality in patients with severe sepsis or septic shock. ${ }^{30-32}$ Further evidence is needed from large, well-designed randomised controlled trials to use IGIV in pneumonia to confirm whether these promising results are applicable to patients with sepsis caused by pneumonia.

This is the first study of a population with CAP in which immunological status was evaluated. Also, three different levels of CAP severity according to the level of care and CURB-65 severity score were separately assessed, showing that hypogammaglobulinaemia may be postulated as a prognostic factor only in critically ill patients with CAP, with an increase in mortality in the presence of low serum immunoglobulin levels. The analysis of the major immunoglobulins and IgG subclasses allowed us to identify that the IgG group especially IgG1 and IgG2 subtypes were those related to prognosis of CAP. Some limitations should be mentioned. Despite strict exclusion criteria, it is unknown whether some patients with low immunoglobulin levels may have had some immunodeficiency disease still undiagnosed. The lack of follow-up during the convalescent phase does not allow distinguishing patients with acquired immunodeficiency caused by CAP from those with deficient immunological status at baseline. On the other hand, although all patients with CAP requiring ICU admission were included in the study, patients with less severe disease, especially those treated as outpatients, may be well under-represented given that physicians did not always order a chest X-ray to establish the diagnosis of CAP, or consider it necessary to draw a blood sample to assess the immunological status on the first day of consultation.

In summary, this study shows that patients with severe CAP admitted to the ICU showed lower levels of circulating immunoglobulins than non-ICU patients and that this IgG deficiency is associated with a higher mortality.

\section{Author affiliations}

${ }^{1}$ Critical Care Unit, Hospital de Mataró, Universitat Autònoma de Barcelona, Ciber Enfermedades Respiratorias, CIBERES, Barcelona, Spain

${ }^{2}$ Unitat Suport Recerca Metropolitana Nord ICS, Santa Coloma de Gramanet, Barcelona, Spain

${ }^{3}$ Research Unit, Hospital de Mataró, CIBEREHD, Barcelona, Spain

${ }^{4}$ Department of Biochemistry, Hospital de Mataró, Universitat Autònoma de Barcelona, Mataró, Barcelona, Spain

${ }^{5}$ Service of Pneumology, Institut Clínic del Torax, IDIBAPS, Hospital Clínic de Barcelona, Universitat de Barcelona, CIBERES, Barcelona, Spain

Acknowledgements The authors thank Marta Pulido, MD, for editing the manuscript and editorial assistance. This article is part of a doctoral thesis, published online beforehand: http//tdx.cat/bitstream/handle/10803/377750/ mcdltt1de1pdf?sequence $=1$, in UAB (University Autonoma Barcelona) digital repository of documentary TDX (Tesis Doctorals en Xarxa).
Contributors MCdIT was responsible for the study design, selection of patients, interpretation of analysis, search of literature, writing and submitting of the manuscript. PT was responsible for the study design, selection of patients and writing of the manuscript. MS-P contributed to the methodological assessment, criteria for analysis, statistical analysis, interpretation of data and writing of the manuscript. EP provided criteria for analysis, and participated in the statistical analysis, interpretation of data and writing of the manuscript. EG and EV were involved in the selection of patients and data collection. JCY and AT contributed to the methodological assessment and writing of the manuscript. JA contributed to the study design, selection of patients, search of literature and writing of the manuscript. All authors have seen and approved the final version of the manuscript.

Funding This work was supported by a grant (08/PI 090448) from Fondo de Investigaciones Sanitarias (FIS) and CIBER de Respiratorio (06/06/0028), Madrid, Spain and a grant from 'Fundació Salut del Consorci Sanitari del Maresme'.

Competing interests None declared.

Patient consent Obtained.

Ethics approval The study protocol was approved by the Ethics Committee of the Consorci Sanitari del Maresme (Barcelona, Spain).

Provenance and peer review Not commissioned; externally peer reviewed.

Data sharing statement No additional data are available.

Open Access This is an Open Access article distributed in accordance with the Creative Commons Attribution Non Commercial (CC BY-NC 4.0) license, which permits others to distribute, remix, adapt, build upon this work noncommercially, and license their derivative works on different terms, provided the original work is properly cited and the use is non-commercial. See: http:// creativecommons.org/licenses/by-nc/4.0/

\section{REFERENCES}

1. Almirall J, Bolíbar I, Vidal J, et al. Epidemiology of community-acquired pneumonia in adults: a population-based study. Eur Respir J 2000;15:757-63.

2. Woodhead MA, Macfarlane JT, McCracken JS, et al. Prospective study of the aetiology and outcome of pneumonia in the community. Lancet 1987;2:671-4.

3. Jokinen $\mathrm{C}$, Heiskanen $\mathrm{L}$, Juvonen $\mathrm{H}$, et al. Incidence of community-acquired pneumonia in the population of four municipalities in eastern Finland. Am J Epidemiol 1993;137:977-88.

4. Mandell LA, Wunderink RG, Anzueto A, et al. Infectious Diseases Society of America/American Thoracic Society consensus guidelines on the management of community-acquired pneumonia in adults. Clin Infect Dis 2007;44:S27-72.

5. Marshall JC. Sepsis: current status, future prospects. Curr Opin Crit Care 2004;10:250-64.

6. Meijvis SCA, van de Garde EMW, Rijkers GT, et al. Treatment with anti-inflammatory drugs in community-acquired pneumonia. $J$ Intern Med 2012;272:25-35.

7. Fernandez-Serrano S, Dorca J, Coromines M, et al. Molecular inflammatory responses measured in blood of patients with severe community-acquired pneumonia. Clin Diagn Lab Immunol 2003;10:813-20.

8. Lucas M, Lee M, Lortan J, et al. Infection outcomes in patients with common variable immunodeficiency disorders: relationship to immunoglobulin therapy over 22 years. J Allergy Clin Immunol 2010;125:1354-60.

9. Skull S, Kemp A. Treatment of hypogammaglobulinaemia with intravenous immunoglobulin, 1973-93. Arch Dis Child 1996;74:527-30.

10. de Gracia J, Vendrell M, Alvarez A, et al. Immunoglobulin therapy to control lung damage in patients with common variable immunodeficiency. Int Immunopharmacol 2004:4:745-53.

11. Orange JS, Hossny EM, Weiler CR, et al. Use of intravenous immunoglobulin in human disease: a review of evidence by members of the Primary Immunodeficiency Committee of the American Academy of Allergy, Asthma and Immunology. J Allergy Clin Immunol 2006:117(4 Suppl):S525-53.

12. Kaul R, McGeer A, Norrby-Teglund A, et al. Intravenous immunoglobulin therapy for streptococcal toxic shock syndrome-a 
comparative observational study. The Canadian Streptococcal Study Group. Clin Infect Dis 1999;28:800-7.

13. Hartung HP, Mouthon L, Ahmed R, et al. Clinical applications of intravenous immunoglobulins (IVlg) — beyond immunodeficiencies and neurology. Clin Exp Immunol 2009;158(Suppl 1):23-33.

14. Alfageme I, Aspa J, Bello S, et al., Grupo de Estudio de la Neumonía Adquirida en la Comunidad. Area de Tuberculosis Infecciones Respiratorias (TIR)-SEPAR. Guidelines for the diagnosis and management of community-acquired pneumonia. Spanish Society of Pulmonology and Thoracic Surgery (SEPAR). Arch Bronconeumol 2005;41:279-89.

15. British Thoracic Society Standards of Care Committee. BTS guidelines for the management of community acquired pneumonia in adults. Thorax 2001;56(Suppl 4):IV1-64.

16. Whicher JT, Price CP, Spencer K. Immunonephelometric and immunoturbidimetric assays for proteins. Crit Rev Clin Lab Sci 1983;18:213-60.

17. de la Torre MC, Bolíbar I, Vendrell M, et al. Serum immunoglobulins in the infected and convalescent phases in community-acquired pneumonia. Respir Med 2013;107:2038-45.

18. De Gracia J, Rodrigo MJ, Morell F, et al. IgG subclass deficiencies associated with bronchiectasis. Am J Respir Crit Care Med 1966;153:650-5.

19. Feldman C, Mahomed AG, Mahida P, et al. IgG subclasses in previously healthy adult patients with acute community-acquired pneumonia. S Afr Med J 1996;86:600-2.

20. Herer B, Labrousse F, Mordelet-Dambrine M, et al. Selective IgG subclass deficiencies and antibody responses to pneumococcal capsular polysaccharide antigen in adult community-acquired pneumonia. Am Rev Respir Dis 1990;142:854-7.

21. Gordon $\mathrm{CL}$, Johnson PD, Permezel M, et al. Association between severe pandemic 2009 influenza A (H1N1) virus infection and immunoglobulin $\mathrm{G}(2)$ subclass deficiency. Clin Infect Dis 2010;50:672-8.
22. Gordon CL, Holmes NE, Grayson ML, et al. Comparison of immunoglobulin $\mathrm{G}$ subclass concentrations in severe community-acquired pneumonia and severe pandemic 2009 influenza A (H1N1) infection. Clin Vaccine Immunol 2012;19:446-8.

23. Justel $\mathrm{M}$, Socias $\mathrm{L}$, Almansa $\mathrm{R}$, et al. IgM levels in plasma predict outcome in severe pandemic influenza. J Clin Virol 2013;58:564-7.

24. Hukuhara $\mathrm{H}$, Shigeno $\mathrm{Y}$, Saito $\mathrm{A}$. Serum levels of healthy adult humans and changes of IgG subclass levels between infected and convalescent phase in respiratory infections. Kansenshogaku Zasshi 1991;65:564-70.

25. de la Torre MC, Palomera E, Serra-Prat M, et al. IgG2 as an independent risk factor for mortality in patients with community-acquired pneumonia. J Crit Care 2016;35:115-19.

26. Bermejo-Martín JF, Rodriguez-Fernandez A, Herrán-Monge R, et al. Immunoglobulins IgG1, IgM and IgA: a synergistic team influencing survival in sepsis. J Intern Med 2014;276:404-12.

27. Werdan K, Pilz G, Bujdoso O, et al. Score-based immunoglobulin G therapy of patients with sepsis: the SBITS study. Crit Care Med 2007;35:2693-701.

28. Pildal J, Gotzsche PC. Polyclonal immunoglobulin for treatment of bacterial sepsis: a systematic review. Clin Infec Dis 2004;39:38-46.

29. Kreymann KG, de Heer G, Nierhaus A, et al. Use of polyclonal immunoglobulins as adjunctive therapy for sepsis or septic shock. Crit Care Med 2007;35:2677-85.

30. Alejandria MM, Langsang MA, Dans LF, et al. Intravenous immunoglobulin for treating sepsis and septic shock. Cochrane Database Syst Rev 2002;(1):CD001090.

31. Turgeon AF, Hutton B, Fergusson DA, et al. Meta-analysis: intravenous immunoglobulin in critically ill adult patients with sepsis. Ann Intern Med 2007;146:193-203.

32. Laupland KB, Kirkpatrick AW, Delaney A. Polyclonal intravenous immunoglobulin for the treatment of severe sepsis and septic shock in critically ill adults: a systematic review and meta-analysis. Crit Care Med 2007;35:2686-92. 